\title{
Challenges in postural orientations for workers away from work with low back pain
}

\author{
Desafios nas orientações posturais para trabalhadores \\ afastados do trabalho com lombalgia
}

Desafíos en las orientaciones postales para los trabajadores afectados del trabajo con lombalgia

\author{
Fernanda Santos Rocha, Maria do Carmo Baracho de Alencar*
}

Universidade Federal de São Paulo (UNIFESP), Santos, SP, Brazil

\begin{abstract}
Introduction: Postural orientations are necessary in cases of low back pain, and challenges arise in chronic cases. Objective: To investigate the challenges in the postural orientation of workers in a situation of absence from work and with chronic low back pain. Methods: The study was divided into two steps. In the first stage, physiotherapists that were taking part in the "Low Back Pain Project" at the Reference Center for Worker's Health in Santos-SP were invited, and a script was used to conduct individual interviews that were recorded for thematic content analysis. In the second stage, there was a selection of workers that were patients attended by the Physical Therapy sector, with chronic low back pain and in a situation of absence from work, and a Discussion Group was conducted with the patients and physical therapists, which was also recorded for content analysis. Results: In stage 1, three physiotherapists aged 26 to 33 years old participated. The statements revealed: intense work demands, little understanding of the patients' difficulties, "stigmas" related
\end{abstract}

*FSR: MS, e-mail: nandarocha85@hotmail.com MCBA: PhD, e-mail: alencar@unifesp.br 
to the situation of absence from work, among others. In stage 2, fourteen workers participated, aged between 47 and 50, of both sexes and different professions along with the three physiotherapists. The group evidenced: difficulties in daily living activities outside the therapeutic environment, disrespect to physical restrictions at work, fear of returning to work, among others. Conclusion: Challenges related to work organization aspects and psychosocial issues were found, and it is necessary to advance in the teaching-learning processes.

Keywords: Back Pain. Physiotherapy. Occupational Health. Teaching. Chronic Pain.

\section{Resumo}

Introdução: Orientações posturais são necessárias em casos de dor lombar, e desafios surgem em casos crônicos. objetivo: Investigar sobre os desafios nas orientações posturais de trabalhadores em situação de afastamento do trabalho e com dor lombar crônica. Métodos: $O$ estudo teve duas etapas. Na primeira etapa foram convidados fisioterapeutas que atuavam no "Projeto Lombalgia" no Centro de Referência em Saúde do Trabalhador de Santos-SP, e utilizou-se um roteiro para a realização de entrevistas individuais que foram gravadas para análise de conteúdo temática. Na segunda etapa houve a seleção de pacientes trabalhadores atendidos pela Fisioterapia, com dor lombar crônica e em situação de afastamento do trabalho, e realizado um Grupo de Discussão com os pacientes e fisioterapeutas, que foi também gravado para análise de conteúdo. Resultados: Participaram da etapa 1 três fisioterapeutas com idade entre 26 e 33 anos. Surgiram nos depoimentos: demandas intensas de trabalho, pouca compreensão acerca das dificuldades dos pacientes, "estigmas" junto à situação de afastamento do trabalho, entre outros. Na etapa 2, participaram quatorze trabalhadores, com idade entre 47 e 50 anos, de ambos os sexos e diferentes profissões, e os três fisioterapeutas. Evidenciaram-se no grupo: dificuldades nas atividades de vida diária fora do ambiente terapêutico, desrespeito às restrições físicas no trabalho, medo do retorno ao trabalho, entre outros. Conclusões: Surgiram desafios relacionados aos aspectos da organização do trabalho e psicossociais, sendo necessário avançar nos processos de ensino-aprendizagem.

Palavras-chave: Idosos. Treinamento Físico. Propriocepção. Equilíbrio Postural.

\section{Resumen}

Introducción: Las orientaciones posturales son necesarias en casos de dolor lumbar, y los desafíos aparecen en casos crónicos. Objetivo: Investigar sobre los desafíos en las orientaciones posturales de trabajadores en situación de alejamiento del trabajo y con dolor lumbar crónico. Métodos: El estudio tuvo dos etapas. En la primera etapa fueron invitados fisioterapeutas que actuaban en el "Diseño Dolor Lumbar" en el Centro de Referencia en Salud del Trabajador de Santos-SP, y utilizó un itinerario para la realización de entrevistas individuales que fueron grabadas para análisis de contenido temático. En la segunda etapa hubo la selección de pacientes trabajadores atendidos por la Fisioterapia, con dolor lumbar crónico y en situación de alejamiento del trabajo, y realizado un Grupo de discusión con los pacientes y fisioterapeutas, que fue también grabado para análisis de contenido. Resultados: Participaron de la etapa 1, tres fisioterapeutas con edad entre 26 y 33 años. Se plantearon en los testimonios: demandas intensas de trabajo, poca comprensión acerca de las dificultades de los pacientes, "estigmas" junto a la situación de alejamiento del trabajo, entre otros. En la etapa 2, participaron catorce trabajadores, con edad entre 47 y 50 años, de ambos sexos y diferentes profesiones, y los tres fisioterapeutas. Se evidenció en el grupo: dificultades en las actividades de vida diaria fuera del ambiente terapéutico, irrespeto a las restricciones físicas en el trabajo, miedo al retorno al trabajo, entre otros. Conclusión: Se plantearon desafíos relacionados a los aspectos de la organización del trabajo y psicosociales, siendo necesario avanzar en los procesos de enseñanza-aprendizaje.

Palabras clave: Dolor Lumbar. Fisioterapia. Salud del Trabajador. Enseñanza. Dolor Crónico. 


\section{Introduction}

Low back pain is a public health issue in many countries [1]. Lumbar spine diseases are very common among the working population and represent from $60 \%$ to $80 \%$ of the diseases faced byworkers [2]. Theyareamong themain causes of disability and absence from work due to illnesses $[3,4]$. They mightresultfrom several causes, which are notisolated such as sociodemographic and behavioral factors, exposure occurred in work activities, obesity, psychological morbidity, among others [5]. Low back pain must be understood as the interaction of biopsychosocial risk factors [6].

Low back pain might become chronic, and chronic pains tend to affect the individual, since they cause disability in everyday activities and those related to work $[7,8]$. Also, by limiting the person regarding the execution of certain activities, they lead to absence from work $[4,9]$. In general, women tend to present higher levels of perception of this pain when compared to men. However, they also present higher resilience to the adversity of the symptoms [10]. This kind of diseases causes significant impact on the individuals' lives due to the physical and psychic suffering they provoke [11]. Physiotherapists' beliefs and attitudes as well as factors related to the therapist-patient relationship influence in the chronic low back pain clinical practice, since when this relationship is good, there are positive effects on the rehabilitation process [12]. Patients' expectations in relation to the treatment and illness prognosis are also relevant to the treatment outcomes [9].

Individuals in absence from work due to illnesses face a constant struggle to prove the illness, which somehow questions their honesty due to the existing doubts [13]. Also, during the medical examinations, they are constantly questioned, as if it was their choice to be in such situation [14]. Therefore, the invisibility of this illness and its symptoms might generate questioning and doubts [13]. Chronic pain is a body experience that aggregates psychic and cultural meanings, which influence the clinical scenario of the ill individual [15]. Along with the experiences of individuals with low back pain and in a situation of absence from work, changes of social roles occur, with social representations that might generate internal and relational conflicts, which might also contribute to an identity of ill and disabled [16].

Physical therapy is indicated to treat low back pain, and the postural orientations are strategies used to prevent greater harm, among other interventions $[17,18]$. Educational practices constitute the basis of health education and should be centered on the problematization of the everyday routine, valorization of the individuals' experiences and those of social groups, as well as the recognition of the affected individuals' different realities [19]. Health education is a process that leads to change of behavior related to one's health, aiming at promoting information and motivation to adopt healthier habits [20].

However, giving orientation to the patient regarding suitable posture and prevention of greater harm involves a teaching-learning process that might present challenges in practice. Physiotherapists in general develop their educational and preventive practices in a dialogical or directive way [21]. In general, physiotherapists show lack of preparation regarding their own qualification in education and planning when working on health education and educational activities [22]. Therefore, educators and learners must overcome uncertainties and social contradictions to transcend reductionist teaching-learning models [23].

This study aimed at investigating the challenges in postural orientation of workers in a situation of absence from work due to chronic low back pain. This study is justified by the need for reflections upon and discussions about the theme aiming at advances in the area.

\section{Methods}

This is an exploratory, descriptive and qualitative study, carried out in two phases, one focusing on the physiotherapists and the other on the patients. This study is linked to the Project 'Lombalgia' (Low back pain project) of the CEREST - Centro de Referência em Saúde do Trabalhador (Workers' Health Reference Center), of Santos/SP. The project Lombalgia was created in 2012 by CEREST, and its general objective was to quantify the low back pain related to work in the municipalities of Santos, São Vicente and Praia Grande, and provide diagnosis and interdisciplinary treatment aiming at reducing absence from work. The total number of physiotherapists working in the project was four, including the researcher.

In the first phase, three physiotherapists linked to the program were invited and took part voluntarily. A semistructured script was elaborated to be used in the interviews with questions related to postural orientation and difficulties they had with patients in a situation of absence from work. A schedule was organized, and the 
interviews were carried out in a reserved place. Each interview lasted around 60 minutes and they were fully recorded and transcribed for content analysis into thematic categories.

The content analysis technique comprises three phases: (1) pre-analysis: it is the organization phase, with floating reading, choice of documents, definition of a corpus of analysis, formulation of hypotheses and the objectives of the analysis; (2) Material exploration or codification; (3) Treatment of results, inference and interpretation [24]. The classification refers to rubrics or classes, which gather elements (register units) under a general title, and this grouping is carried out due to the common characteristics of these elements [24]. After data treatment, the themes that aggregate some register units were listed, therefore originating the thematic categories.

The second phase selected the patients assisted through the patients' records created in service from January to July 2014. The type of data obtained from the physiotherapeutic evaluation was: demographic, telephone, municipality of residence, whether the patient had been or still was in a situation of absence from work, profession, pain complaints and body parts, among others. The inclusion criteria for the second phase were: workers with chronic low back pain, aged 35 to 50, who had been or were still in a situation of absence from work and referred by the medical team to the Lombalgia Project, those that had been in physical therapy assistance with the occurrence of at least 15 (fifteen) uninterrupted sessions in the relevant period. Individuals with mental disorder, rheumatic illnesses, acquired or congenital physical disability and pregnant women were excluded from the study.

A total of 21 (twenty-one) individuals of both sexes and different jobs met the selection criteria. A Discussion Group was organized with the participation of 14 patients and the presence of the physiotherapists. A semistructured script was devised and used with questions concerning the individuals' perceptions regarding postural orientations. The discussion group consists in a social analysis qualitative practice [25]. Discussion groups are characterized by a technique of research and opinions through interactive, discursive and collective processes of these opinions, therefore, they represent an important tool to reconstruct social contexts and individuals' actions [26]. The discussion group occurred with the presence of two researchers, one of them coordinated the meeting aided by the other as a vicecoordinator. Initially, the proposal of the meeting was presented to the participants and later the debate was started in group from the prompt questions listed in the script. The discussion group lasted 120 minutes, the contents of the meeting were recorded and fully transcribed for content analysis.

This research was approved by the Research Ethics Committee of the Federal University of São Paulo UNIFESP, Technical Opinion no 930842 and date of report 13/01/2015.

\section{Results}

Interviews with the physiotherapists

Three physiotherapists that worked in the Lombalgia Project took part in the interview. Their ages were 26, 28 and 33 , two were male and one was female. Their time of experience in the profession was 4, 6 and 10 years and the time they had been linked to the project was two years. Also, two of them had a $12 \mathrm{~h} /$ day workload. Regarding postural orientation during treatment, they usually destined eight to ten minutes to it at the end of each appointment.

In this phase, four thematic categories were listed: Fast-paced work; absence from work; patients'learning; the physiotherapist's teaching role.

The participants' statements will be presented using identification codes (F1, F2, F3) in order to protect their identity. Table 1 demonstrates the thematic categories and the physiotherapists' statements.

Table $\mathbf{1}$ - Thematic categories and the physiotherapists' statements

\begin{tabular}{|c|c|c|}
\hline $\begin{array}{l}\text { Thematic } \\
\text { categories }\end{array}$ & Interviewees & Statements \\
\hline Fast-paced work & F3 & $\begin{array}{l}\text { "[...] I do not stop to give } \\
\text { the orientation at a specific } \\
\text { moment, there is no time! " }\end{array}$ \\
\hline $\begin{array}{l}\text { Absence from } \\
\text { work }\end{array}$ & F2 & $\begin{array}{l}\text { "[... many patients do not } \\
\text { want to go back to work, due } \\
\text { to the pain, not all of them, I } \\
\text { cannot generalize, but many } \\
\text { do not want to resume work!" }\end{array}$ \\
\hline Patients' learning & $\mathrm{F} 1$ & $\begin{array}{l}\text { "[...] some learn, others } \\
\text { understand it at the time } \\
\text { of instruction, but then } \\
\text { forget it, I do not know if } \\
\text { we are not able to teach, } \\
\text { or if they cannot learn." }\end{array}$ \\
\hline $\begin{array}{l}\text { Physiotherapist's } \\
\text { teaching role }\end{array}$ & F3 & $\begin{array}{l}\text { "[...] the teaching process } \\
\text { takes place...but not the } \\
\text { learning process." }\end{array}$ \\
\hline
\end{tabular}


Group of discussion results

Fourteen patients took part in this group, along with the three physiotherapists and two researchers. From the patients, ten were men (71\%), four were women (29\%), nine were in the age range 47 to 50 (64\%) and eight were married (57\%). Most (8) had not complemented elementary education (57\%), and thirteen lived in Santos (93\%). The majority (12) were still in a situation of work absence paid by the INSS (Brazilian social security system) (79\%), and some (2) had already resumed work (14\%), one was absent from work for the second time in a sick leave after having returned to work (7\%). They had different jobs: brick layers, domestic servants, dockers, among others, but all activities required some physical effort.

A code of identification was also used for the patients participating in the research (P1, P2, etc). Table 2 demonstrates the thematic categories listed and the patients' statements.

Table 2 - Thematic categories and patients' statements

\begin{tabular}{|c|c|c|}
\hline $\begin{array}{l}\text { Thematic } \\
\text { categories }\end{array}$ & Patients & Statements \\
\hline $\begin{array}{l}\text { Importance of } \\
\text { the physical } \\
\text { therapy }\end{array}$ & P7 & $\begin{array}{l}\text { "[...] if there was no physical } \\
\text { therapy we would be using a } \\
\text { wheelchair...it helps us to sit, lie } \\
\text { down and get up..." } \\
\text { "[...] we learned it and I am } \\
\text { practising at home, really, we could } \\
\text { see what's right and what's wrong, } \\
\text { so we have to continue at home." }\end{array}$ \\
\hline $\begin{array}{l}\text { Difficulties } \\
\text { in postural } \\
\text { adaptation } \\
\text { in everyday } \\
\text { situations }\end{array}$ & $\begin{array}{l}\text { P6 } \\
\text { P10 }\end{array}$ & $\begin{array}{l}\text { "[... I l leave this place feeling well, } \\
\text { go somewhere else and already } \\
\text { feel handicapped." } \\
\text { "[... if I try to go from here to } \\
\text { there, it starts all over again..." }\end{array}$ \\
\hline $\begin{array}{l}\text { Disrespect } \\
\text { to the } \\
\text { restrictions } \\
\text { and fear of } \\
\text { going back to } \\
\text { work }\end{array}$ & P3 & $\begin{array}{l}\text { "[...] then you have the physical } \\
\text { therapy here, and go lift sixty, } \\
\text { seventy kilos (at work)! ..." } \\
\text { "[...], but the bosses, our bosses, } \\
\text { they don't want to know...you have } \\
\text { to deal with it! I unload the truck, } \\
\text { park it and unload it by myself" }\end{array}$ \\
\hline
\end{tabular}

\section{Discussion}

Regarding the results of phase 1 , the health assistance services rendered to the workers registered in the Brazilian National Health System - SUS face in general a great demand. The requests for physical therapy in this study depended on a doctor's referral, which generated difficulties to the continuity of the treatment that was interrupted until the patient managed to get another service order. Due to the importance given to the physical therapy assistance, the possibility of delay to resume the treatment generated insecurity in the patients being assisted.

Fast-paced work appeared in the statements, since there was high demand of work related to the high number of patients to be assisted, time controls and under-sized teams, which influenced the time and organization of the postural orientations. Therefore, due to the fastpaced work and relatively high number of patients per appointment, the interviewees pointed out lack of time for the necessary procedures. In this period, the interventions carried out by the team included: electrothermotherapy and/or kinesiotherapy and postural orientations. Later, the Posture School was created, which favored the process, however, this did not occur during this study. A study reported that the Posture School has improved the patients' quality of life and reduced pain in patients with chronic low back pain [27].

In relation to the situation of absence from work, and in the physiotherapists' perceptions, the patients showed lack of interest in the learning process, resulting in possible postural negligence in everyday activities, which should be avoided. Also, some patients were suspected to having been trying to keep the social security benefit and for this reason, they were not paying attention to the postural care. Such situation might interfere in the therapeutic relationship.

Individuals in absence from work already face a constant fight to prove their illness and their disabilities, which generates some suffering $[13,14]$. The subjectivity involved and related to the invisibility of the illness and the symptoms might result in questioning and doubts about the truthfulness of the facts. Therefore, some social stigma might arise that should be avoided.

When an illness becomes chronic, there is also a background and some development that permeates their relationships with themselves and with others [28]. Therefore, patients' suffering should be taken into consideration, their life conditions, expectations, beliefs, experiences and lifestyle as well as their way of being and reacting, which is influenced by the society to which they belong [16]. Also, the physiotherapists' clinical interventions should favor a dynamic relationship, where both the physiotherapist and the patient must be involved in a kind of interchange, instead of being separated and distanced one from another, and maybe 
the professional qualification should reflect upon it [12]. Educational practices must problematize the everyday life and value the individual experiences and those of social groups, in addition to promoting discussions and reflection [20].

As regards teaching and postural orientations, in the physiotherapists' perceptions, the patients' low level of education was one of the aspects that hampered their understanding of the need to include postural care in their everyday routine. Regarding their low level of education, there are reports in the literature that individuals with higher level of education demonstrate lower prevalence of low back pain when compared to those with intermediate or lower levels [29]. Therefore, another issue to be taken into consideration is the ways and means of communication used (even regarding language) and stimulating learning.

When the physiotherapists' role as educators was evaluated, the interviewees evidenced a unilateral approach to the process, with little attention being given to the patients' life experience and difficulties, also resulting from the short time destined to the postural orientations, the fast-paced work and the number of patients. Listening attentively to the patients would be necessary. In another study, the professional did not learn to exercise their listening skills to the benefit of the user [30]. Therefore, the physiotherapist might not be aware in general of the reasons why the patients do not use the postural orientations given, which are usually ascribed to lack of understanding or interest and attention by the patients, which suggest that some pre-judgement should be avoided. The physical therapy professional should conciliate the subjective expression with the technical-scientific knowledge to seek new strategies of intervention and solution to the problems [31].

Considering phase 2, the Discussion Group, the participants emphasized the importance of the physiotherapists' contribution to the rehabilitation process and return to daily living activities, highlighting postural orientation. The patients feel welcomed in the rehabilitation environment, due to the feeling of belonging to the group of people that are also ill and the care received, which helps them face the exclusion process lived due to the fact of being ill [32]. Also, through the learning achieved, it was possible for most patients to distinguish what was considered "right" or "wrong" in relation to postural care and in the therapeutic and domestic environments.
However, in relation to the everyday difficulties, the group raised elements in their statements that indicated some difficulties related to the teaching outside of the therapeutic environment. Some situations were found in everyday routines that favored the appearance and worsening of the symptoms, such as: improper sidewalks and the risk of falling down when going on or off the bus, for example, long walks many times required due to lack of money to pay for the bus fare, living far which involved going up and down hills on foot (for lack of bus access), among others. This evidenced the absence of postural orientation practices regarding their routine, and which might promote reflections on the strategies to face these real everyday difficulties. Apparently, there was a sense of security for being in a therapeutic treatment for their illness, which could be understood as the attention received that legitimized their illness.

Regarding the negligence of work restrictions, the patients had already been in physical therapy treatment before without being in a situation of work absence paid by the social security institute (INSS), obtaining a doctor statement that referred them to the physical therapy. However, some situations did not favor that treatment or the clinical condition of the individuals, since some of the patients returned to work and resumed the same activities that had caused their illnesses, without any consideration of their physical restrictions. This aspect was also observed with those who had returned to work after having been in a sick leave paid by the INSS. Therefore, the workers' reinsertion in improper dynamics, with unfavorable work organization and with disrespect to the physical restrictions might favor the worsening of the clinical situation32. Therefore, the statements that appeared in the group highlighted that postural orientations were not compatible with the patients' experiences in their everyday life and work routine, and commonly resulted in the recurrence of the painful symptoms, generating insecurity and fear and the risk of dismissal. Therefore, the workers might experience some fear to resume their work and submit to the routine that made them sick $[32,33]$.

The transformations of productive processes and the ways of organizing work might impact dramatically the workers' life and health and the health services might have difficulties to deal with these realities. Also, resuming work without the required discharge from the physical therapy treatment that has been indicated by the professional might generate a feeling of impotence in both sides, imposing challenges for 
both the professionals and the patients. Feelings of fear and insecurity might influence the expectations of rehabilitation and professional life. The frequency of signals and symptoms also influenced the perception of the illness [8].

\section{Conclusion}

This study evidenced some challenges and promoted some reflection upon the postural orientations and the physiotherapists' role as educators. It is important for the physiotherapists to understand that health education goes beyond biological causes and issues in cases of chronic pain, suggesting the need for reflection on these practices.

Among the challenges for postural orientations pointed out by the physiotherapists were: the need for 'proper' time for postural orientations, so that greater attention is given to them. Therefore, undersized teams should be avoided, pointing out work organization issues; social stigmas that lead to a pre-judgment of the cases without contextualizing the individuals' difficulties should also be prevented; communication difficulties (regarding language) mainly in relation to low schooling patients should be taken into consideration and overcome the perception that the learning process is unilateral, and the physiotherapist only teaches while the patient only learns.

For the patients, the challenges were mostly related to the difficulties to put into practice what they had learned, for several reasons outside the therapeutic environment, mainly related to transportation and economic issues. Such practices face the great challenge of problematizing the daily living activities and create strategies to present solutions that are compatible to the patients' reality. The most evidenced aspect was the fear of returning to work to the disregard of physical restrictions in the work environment and the recurrence and worsening of painful symptoms and the risk of being dismissed. Current situations in the work environment have not favored the reinsertion of individuals with low schooling levels and that are ill, also imposing challenges to the processes of returning to work, mainly in unsuitable work conditions.

Therefore, group educational practices that are interdisciplinary and make sense to the patients are recommended. This study presented some limitations, among them is the small number of patients in the sample investigated, in addition to belonging to a single health service, therefore, the findings cannot be generalized. The results obtained should stimulate new research on the theme and contribute with reflections on and advances of the physical therapy in the workers' lives.

\section{References}

1. Hoy D, Blain C, Willians G, March L, Brooks P, Blyth F, Fiona $B$, et al. A systematic review of the global prevalence of low back pain. Arthritis Rheum; 2012;64(6):2028-2037.

2. Campbell P, Wunne-Jones G, Muller S, Dunn KM. The influence of employment social support for risk and prognosis in nonspecific back pain: review and critical synthesis. Int Arch Occup Environ Health; 2013;86(2):119-137.

3. Finger ME, Selb M, Bie RD, Escorpizo R. Using the International Classification of Functioning, Disability and Health in Physiotherapy in Multidisciplinary Vocational Rehabilitation: a case study of low back pain. Physiother Res Int; 2014;12:1088-2454.

4. Meziat FN, Silva, GA. Invalidez por dor nas costas entre segurados da Previdência Social do Brasil. Rev Saude Publica; 2011;45(3):494-502.

5. Ferreira GD, Silva MC, Rombaldi AJ, Wrege ED, Siqueira FV, Hallal PC. Prevalência de dor nas costas e fatores associados em adultos do Sul do Brasil: estudo de base populacional. Rev Bras Fisioter; 2011;15(1):31-36.

6. Silva MC, Fassa AG, Valle NCJ. Chronic low back pain in a Southern Brazilian adult population: prevalence and associated factors. Cad Saúde Pública; 2004;20(2):377-85.

7. Alencar MCB, Terada TM. 0 afastamento do trabalho por afecções lombares: repercussões no cotidiano de vida dos sujeitos. Rev Ter Ocup Univ São Paulo; 2012;23(1):44-51.

8. Malta DC, Oliveira MM, Andrade SSCA, Caiffa, WT, Souza, MFM, Bernal, RTI. Fatores associados à dor crônica na coluna em adultos no Brasil. Rev Saúde Pública; 2017;supl 1:1-12. 
9. Hallegraef JM, Krijnen WP, Schans CP Van Der, Greef MHG. Expectations about recovery from acute non-specific low back pain predict absence from usual work due to chronic low back pain: a systematic review. Journal Physiother; 2012; 58:165-172.

10. Zavarize SF, Wechsler SM, Lima AB, Martelli, A. A dor lombar crônica: implicações no perfil criativo como estratégia de enfrentamento. J Manag Prim Health Care; 2014, 5(2):188-194.

11. Martinez MDCP, Villarreal-Ríos E, Vargas-Daza ES, Martinez-Gonzáles L, Galicia-Rodrigues L. Costo institucional del paciente com incapacidad temporal para el trabajo por lumbalgia mecánica. Rev Asoc Argent Ortop Traumatol; 2013;78(3):113-119.

12. Gardner T, Refshauge K, Smith L, MacAuley J, Hubscher M, Goodall S. Physiotherapists' beliefs and attitudes influence clinical practice in chronic low back pain: a systematic review of quantitative and qualitative studies. J Physiother; 2017;63:132-143.

13. Valença JBM, Alencar MCB. O afastamento do trabalho por dor lombar e as repercussões na saúde: velhas questões e os desafios que continuam. Cad Bras Ter Ocup; 2018;26(1):119-127.

14. Zavarizzi CP, Alencar MCB. Afastamento do trabalho e os percursos terapêuticos de trabalhadores acometidos por LER/DORT. Saúde debate; 2018;42:113-124.

15. Sarti AS. A dor, o indivíduo e a cultura. Saude soc; 2011;20(1):03-13.

16. Alencar MCB, Valença JBM. Afastamento do trabalho e funcionalidade: o caso de trabalhadores adoecidos por doenças da coluna lombar. Cad Ter Ocup UFSCar; 2016;24(4):755-763.

17. Pires RAM, Souza A. Análise dos efeitos da tens, cinesioterapia e o método Mackenzie para redução da dor em pacientes com lombalgia. Universitas: Cienc Saúde; 2012;10(2):127-135.

18. Guastala FAM, Guerini MH, Klein PF, Leite VC, Capellazo R, Facci LM. Effect of global postural re-education and isostretching in patients with non- specific low back pain: a randomized clinical trial. Fisiot Mov; 2016, 29 (3):515-25.
19. Silva, JL. A prática educativa como expressão da prática profissional no contexto da equipe de Saúde da Família no Município do Rio de Janeiro. 2010. 149f. Dissertation [Master's degree]. Rio de Janeiro: Universidade do Estado do Rio de Janeiro; 2010.

20. Reis DM, Pitta DR, Ferreira HMB, Jesus MCP, Moraes MEL, Soares MG. Educação em saúde como estratégia de promoção de saúde bucal em gestantes. Cienc saúde coletiva; 2010; 15(1): 269-276.

21. Ghizoni AC, Arruda MP, Tesser, CD. A integralidade na visão dos Fisioterapeutas de um município de médio porte. Interface: Comunic, saúde, educ; 2010;14(35):825-837.

22. Neuwal MF, Alvarenga LF. Fisioterapia e educação em saúde: investigando um serviço ambulatorial do SUS. Boletim Saúde. 2005;19:73-82.

23. Ramos FEALO, Lacerda ABM, Soares VMN, Willing MH. A. Atividade de grupo como estratégia de educação em saúde auditiva de trabalhadores de um serviço de manutenção hospitalar. Audiol Commun Res; 2017;22e:1-8.

24. Bardin L. Categorização. In: Bardin L, org. by. Análise de conteúdo. São Paulo: Edições 70; 2011.

25. Meinerz CB. Grupos de discussão: uma opção metodológica na pesquisa em educação. Educ Real; 2011;36(2):485-504.

26. Weller W. Grupos de discussão na pesquisa com adolescentes e jovens: aportes teórico-metodologico e análise de uma experiência com o método. Rev Educ Saúde; 2006;32(2):241-260.

27. Santos MF, Inumaru SMSM. Avaliação da dor em portadores de lombalgia crônica antes e após a participação no programa da escola postural na clínica escola da UEG. Rev Movimenta; 2011;4(2):119-129.

28. Canguilhem C. 0 normal e o patológico. Rio de Janeiro: Forense; 2014:189-190]

29. Batista AAS, Henschke N, Oliveira VC. Prevalence of low back pain in different educational levels: a systematic review. Fisioter Mov; 2017;30(Suppl 1):S351-61.

30. Lopes SRS, Piovesa ETA, Melo LO, Pereira MF. Potencialidades da educação permanente para a transformação das práticas de saúde. Interface: Comun Cienc Saúde; 2007;18(2):147-155. 
31. Caetano VC, Cruz T, Leite ICG. Perfil dos pacientes e características do tratamento fisioterapêutico aplicado aos trabalhadores com LER/DORT em Juiz de Fora, MG. Fisioter Mov; 2010;23(3):451-60.

32. Toldrá RC, Daldon MTB, Santos MC, Lancman S. Facilitadores e barreiras para o retorno ao trabalho: a experiência de trabalhadores atendidos em um centro de referência em saúde do trabalhador - SP, Brasil. Rev Bras Saúde Ocup; 2010;35(121):10-22.
33. Ramos MZ, Tittoni J, Nardi H.C. A experiência de afastamento do trabalho por adoecimento vivenciada como processo de ruptura ou continuidade nos modos de viver. Cad Psicol Soc Trab; 2008;11(2):209-221.

Received in 22/07/2017

Recebido em 07/22/2017

Recibido en $22 / 07 / 2017$

Approved in 28/08/2018

Aprovado em 08/28/2018

Aprobado en 28/08/2018 